having been made by specific endowment. Advantage was taken of this enforced restriction in the activities of certain members of the scientific staff to proceed with research work and publication of results. The South Oceanic or Witney Wing was completed, one floor being adapted to house the Rothschild collection of birds, which has been acquired for the Museum by the widow and family of the late Mr. Harry Payne Witney. At the close of this, the twenty-fifth year of his tenure of office as president of the Museum, Prof. Osborn tendered his resignation, much to the expressed regret of the trustees and the authorities of the City of New York. Prof. Osborn has been succeeded as president by Prof. F. Trubee Davison; but in recognition of his great services to the Museum, Prof. Osborn has been elected honorary president for life.

\section{Excavations in Iraq}

According to a statement issued by Prof. J. H. Breasted and circulated by Science Service (Washington), after a visit to the various excavations in the Near East now being conducted by the Oriental Institute of Chicago, the tablet containing the list of kings of Assyria recently discovered at Khorsabad by the expedition under Dr. H. Frankfort, will shortly be shipped to the United States for study and publication. The lists are in cuneiform on two sides of a baked clay tablet and contain the names of ninetythree kings. They end about 730 B.c. just before the reign of Sargon II, which began in 722 B.c. As the lists cover a period of thirteen or fourteen hundred years, they carry back Assyrian history to about 2200 B.c. and add an unbroken line of eight new kings preceding Ushpia, previously the earliest known king, who ruled not long before 2000 в.c. Prof. Breasted also refers to the discovery at Khorsabad of the temple of Nabu or Nebo, mentioned by the prophet Isaiah, which he regards as one of the most important finds made by the expeditions of the Institute during the past season. As Nabu was the god of writing, his temple should, Prof. Breasted expects, contain records of importance. At Persepolis, where the excavations are in charge of Dr. E. N. Herzfeld, what would appear to be a library of records in the Elamite language has been unearthed in moving the field railroad. Although at present only very imperfectly examined, the tablets would appear to contain records connected with the building of the palaces.

Some further particulars of the results of the excavations of the Oriental Institute are given by Dr. H. Frankfort in a preliminary account in the Times of July 10 and 11. At Tell Asmar, a site on the east of the Tigris and Diala, fifty miles from Baghdad, identified with the ancient Eshnunna, in the course of a successful search for evidence which might afford chronological relation with the tombs of Ur, buildings were discovered belonging to the Akkadian period which have afforded the first view of the arrangements, domestic and other, of structures of the time of Sargon I. Dr. Frankfort notes that certain features of the elaborate sanitary system follow the European rather than the oriental type. A temple, "the House of Abu", Lord of Vegetation, originally founded in preAkkadian times but twice reconstructed, has yielded some remarkable reliefs, among which one represents the central mystery of the fertility cult, the marriage of the god and goddess, a subject of which there are hints in Babylonian texts, but no representation known elsewhere. Equally noteworthy are representations of the god partly in the form of a snake and of a deity attacking a sevenheaded monster with a spear, probably the oriental prototype of Heracles and the Hydra. A hoard of jewellery in a building of considerable size shows survivals from the period of the tombs of Ur. At Kafaje, a site 15 miles south-west of Tell Asmar, was found the earliest known example of town planning, in which closely packed houses of Sargonid date formed a long street running the whole length of the town from north-west to south-east, with side streets running at right angles from it. Dr. Frankfort considers that the evidence points to a closer relation of the region east of the Tigris to the mountaineers to the east and the north than to the Babylonians of the plains.

\section{Megaliths of the Trent Basin}

Bx the publication of the map of the Trent Basin (Ordnance Survey Office, Southampton. $4 s$. net) the scheme for a complete survey of the megalithic and allied remains of England and Wales is nearly halffinished. It is, in fact, the fourth of the series of twelve half-inch maps to be issued; and two more are in course of preparation. The survey of the Trent Basin is the work of Mr. C. W. Phillips. In one respect his work is especially noteworthy. It has resulted in the discovery of a previously unknown group of long barrows on the Lincolnshire Wolds, centred on two areas, the valley of the Swinhope Beck in the north and the terminal massif between Alford and Spilsby on the south, their distribution being rigidly confined to the chalk. Happily, it would appear, they have not been disturbed, except in two instances, in which digging does not appear to have penetrated to the deposit. It is regrettable that the same cannot be said of the western of the two groups into which the megalithic monuments of the area fall. In Derbyshire and on the confines of Cheshire and Staffordshire, the monuments, though not numerous, are among the most famous and interesting of their kind in England. Unfortunately, Arbor Low is the only one which has been investigated scientifically. The others were examined in the eighteenth or nineteenth century, and in some instances it is now impossible to determine their exact character archæologically, either from examination of the monuments themselves or the records where any exist. One feature in which the map of the Trent Basin differs conspicuously from its immediate predecessor, the map of Neolithic Wessex, is in the absence of any indication of ancient vegetation. This is due to differences of opinion among 'vegetarian experts'. 